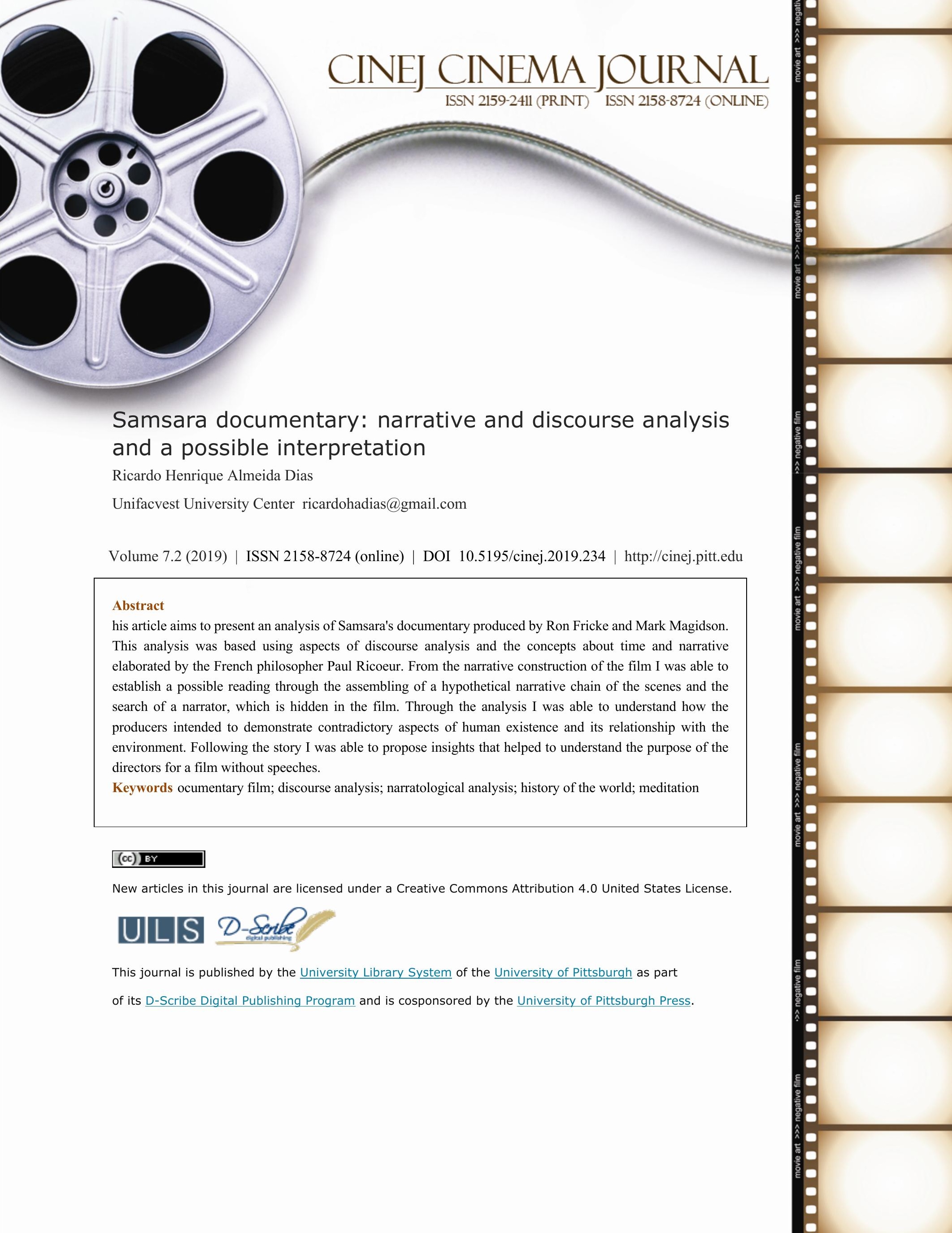




\section{Samsara documentary: narrative and discourse analysis and a possible interpretation}

\section{Ricardo Henrique Almeida Dias}

\section{Introduction}

In this article I present a narratological and discursive analysis of the film Samsara, directed by Ron Fricke and produced by Mark Magidson. Samsara was released in 2011 and is a film without speeches, being 99 minutes of exposure of images from different parts of the world. There is no narrator explaining the places and sequences, which makes the film relevant to be researched. The narrator does not speak, but becomes present in the choice of images and, especially, in the connections between the images that the directors propose, which invoque the audience to construct their own interpretations and attributions of meaning as the sequences unfold.

The film was produced in five years in 25 different countries, showing various situations through the prism of the Sanskrit term samsara, which signifies the eternal cycle of the ever turning wheel of life. According to the information contained in the film's official website, this endless cycle is the starting point of the filmmakers, who sought the interconnection that runs through our lives.

By dispensing with dialogue and descriptive text, Samsara subverts our expectations of a traditional documentary, instead encouraging our own inner interpretations inspired by images and music that infuses the ancient with the modern. Samsara explores the wonders of our world from the mundane to the miraculous, looking into the unfathomable reaches 
of man's spirituality and the human experience. Neither a traditional documentary nor a travelogue, Samsara takes the form of a nonverbal, guided meditation. Through powerful images, the film illuminates the links between humanity and the rest of nature, showing how our life cycle mirrors the rhythm of the planet. ${ }^{1}$

These characteristics of the film make it relevant for reception studies, in which the audience has a constitutive role in the interpretation and construction of meanings in relation to the art. Thus, in this study I have chosen discourse analysis as a framework in order to establish possible meanings and readings for the interpretation of the film. I also took into account the narrative studies developed by Paul Ricoeur to understand how Samsara is a narrative even without the presence of a narrator in the traditional ways that speaks and explains. Samsara becomes a narrative through the intersubjective play between the producers of the film and the audience.

\section{Discourse analysis}

The discourse analysis that I have chosen for this study was developed in the 60's in France by Michel Pêcheux. In this framework language is not transparent, as well as admits that the relationship between man, thought and world does not happen directly but rather mediated. The notion of discourse, as an effect of meanings among interlocutors, creates conditions for 
understanding these mediated relations. So, we search for understanding how the language makes sense, as a symbolic work and part of the general social work, constitutive of man and his history, conceiving language as a necessary mediation between man and natural and social reality. This mediation, which is the discourse, makes possible both permanence and continuity as well as the displacement and transformation of man and the reality in which he lives. In the case of the film Samsara, the analysis that I will propose has a materiality that is historical. In the same way that the senses can be several, they cannot be anyone.

Discourse analysis seeks to understand the mechanisms that work in the construction of discourses, and some of these mechanisms are the conditions in which discourses are produced. For Orlandi (2005, p. 30), discourse analysis enables the investigation of the language production processes, not just their products. "We can consider the conditions of production in the strict sense and we have the circumstances of the enunciation: it is the immediate context. And if we consider them broadly, the conditions of production include the socio-historical, ideological context".

For Pêcheux (1988), the meaning of a word, an expression, a proposition, etc., does not exist in itself, but is determined by the positions that are at stake in the socio-historical process in which words, expressions and propositions are produced.

We could sum up this thesis by saying that words, expressions, propositions, etc., change their meaning according to the [ideological] positions held by those who use them, which 
signifies that they find their meaning by reference to those positions; that is, by reference to the ideological formations in which those positions are inscribed (p. 160).

Along with the notion of conditions of production, other relevant concept of discourse analysis is the interdiscourse. For Orlandi (2005), this is defined as which speaks before and elsewhere for the production of discourses.

(...) is what we call discursive memory: the discursive knowledge that makes it possible for all to say and that returns in the form of the pre-constructed, the already-said that is at the base of the sayable, sustaining each taking of the word. The interdiscourse provides sayings that affect the way the subject means in a given discursive situation (p. 31).

According to Montgomery and Allan (1992) Pêcheux distinguish two elements of the thread or interdiscourse, which are the preconstructed and articulation. They are both embedded in the materiality of the human subject and his or her Other.

Briefly, the preconstructed in this formulation corresponds to the "always-already there" of the ideological interpellation as it supplies/imposes already available positions: that is, the "raw material" of "reality" and its "meaning" in the form of universality (the "world of things", the "evident facts" or "what everyone knows to be real") or obviousness. Thus the preconstructed stands in contrast with that which is said to be "constructed" by the utterance. Alternatively, the element of articulation (support effect) sustains the human subject in a relation to that meaning ("as I have said before" or "as I shall say afterwards") as if it were something exclusively internal to him or her (p. 8).

On the discursive memory Pêcheux (1999) emphasizes that it should not be understood in the directly psychological sense of individual memory, but in the crisscrossed meanings of the mythic 
memory, of the social memory inscribed in practices and the constructed memory of the historian.

The author considers memory as a structuration of complex discursive materiality, understood in

a dialectic of repetition and regularization:

(...) discursive memory would be what, in the face of a text that emerges as an event to be read, reinstates the implicit ones (that is, more technically, the pre-constructed, quoted and reported elements, transverse discourse, etc.) that your reading needs: the condition of the readable in relation to the readable one itself. (...) The question is to know where these implicit reside, who are absent because of their presence in reading the sequence (...) (p. $52)$.

In this way, I searched for implicit meanings in the sequence proposed by Fricke and Magidson in Samsara. Discourse analysis allows us to establish possible readings. Thus, I searched for possible readings for the film, proposing the construction of a narrative based on the sequence of images. In this construction I used the studies of Paul Ricoeur on the narrative to understand the relations between time, narrative and the human perception of these relations.

\section{Narrative of Paul Ricoeur}

The main thesis defended by Ricoeur is that the world exhibited by any narrative work is always a temporal world. He states that time only becomes human time to the extent that it is organized after the manner of a narrative. Narrative, in turn, is meaningful to the extent that it portrays the features of temporal experience. 
On the other hand, the narrative is meaningful in that it sketches out the traces of temporal experience. "The narrative reads time and teaches how to read it" (1997, p. 22). For Ricoeur, there is a functional unity between the various modes and narrative genres.

My basic hypothesis in this regard is this: the common characteristic of human experience, signalled, articulated, and elucidated by the act of narrating in all its forms, is its temporal character. Everything that has been told happens in time, is rooted in it, develops temporally, and what develops over time can be narrated (2000, p. 190).

Reinforcing the relationship between narrative and temporality, Ricoeur demonstrates that there is only the possibility of recognizing every temporal process as such insofar as it can be narrated, one way or another. Thus, a characteristic of intelligibility inherent to the act of narration arises, in which Ricoeur will point to the fecundity of the notion of the plot. "The plot is the set of combinations by which events turn into a story or - consecutively - a story is drawn from events" (id., p. 192). It is a mediator between the event and the story, meaning that nothing is an event if it does not contribute to the advancement of a story.

An event is not just an incident, something that happens, but a narrative component. Further expanding the scope of the plot, I will say that the plot is the intelligible unit that composes the circumstances, ends and means, initiatives and unwanted consequences (ibid., p. 192). 
An event must be more than a singular occurrence, and a story must be more than an enumeration of events in a serial order. A story must organize events into an intelligible totality, so that one can always inquire what the theme of history is.

To follow a story is to move forward in the midst of contingencies and peripeteia under the guidance of an expectation that finds its fulfilment in the "conclusion" of the story. This conclusion is not logically implied by some previous premises. It gives the story an "end point" which, in turn, furnishes the point of view from which the story can be perceived as forming a whole. To understand the story is to understand how and why the successive episodes led to this conclusion, which, far from being foreseeable, must finally be acceptable, as congruent with the episodes brought together by the story (1997, p. 105).

Finally, Ricoeur emphasizes that story can not be completely separated from the report, since story cannot be separated from the action that involves the agents, ends, circumstances, interactions and consequences desired or undesirable, being the plot the basic narrative unit which integrates these heterogeneous ingredients into an understandable whole.

Thus, the plot has also revealed something comparable to this predicative assimilation: it has also been presented as a grasp together, which integrates events into a story, and which composes, together, such heterogeneous factors as the circumstances, the characters with their projects and motives, interactions involving cooperation or hostility, help or impediment, and, finally, causality. Every plot is this form of synthesis of the heterogeneous (2000, p. 197).

For Ricoeur (1997, p. 10) the plot of a narrative is comparable to this predicative assimilation.

'It 'grasps together' and integrates into one whole and complete story multiple and scattered 
events, thereby schematizing the intelligible signification attached to the narrative taken as a whole".

Paul Ricoeur calls narrative insight the understanding put at stake by the activity of following a story and defends the thesis that the historical explanation by laws, regular causes, functions and structures is incorporated to this narrative understanding. Ricoeur's assumptions about narrative and plot as a convergence of events in a story, composing factors such as circumstances, characters with their intentions and motives, interactions of cooperation or hostility, help or impediment, and causality may be fertile for the analysis of the Samsara film.

\section{Narratological and discoursive analysis}

In the scenes before the entry of the film's title are shown the Indonesian Tari Legong dancers, then going on to the scenes of the erupting Kilauea volcano in Hawaii, until they reach the iconic gold mask of Tutankhamun. This preamble shows us the leitmotiv of the whole film, which synthesizes the dual experience between man and nature. The Earth in motion, represented by the volcanic eruption, and the human in motion, represented by the dancers. In the midst of this dualistic experience lies the aspiration of man for eternity, represented by the death mask of the pharaoh. The volcano also alludes to the beginnings of the constitution of the planet, since it is 
remnant of the formation of the Earth 4.5 billion years ago. Duality is reinforced by man's attempt to confuse his finite temporality in a natural temporality in a quasi-eternal geological time with the use of the gold death mask.

After the film's title is shown, the aerial display of the set of temples from Bagan in Myanmar begins, until arriving at a monastery in the Himalayan region of Ladakh, in the north of India. There, monks carefully prepare a sand mandala. Mandalas represent, in Indian cultures, the whole universe. In this way, the monks create the symbolic representation of the universe. Then, the One Thousand Hands Dance are shown in China. They still do not dance, and the first dancer, who is the only one on whom the face is shown, closes her eyes. After this, a long sequence of images of nature begins, without human presence, but with signs of its presence. Images of deserts, the monoliths of Adiyaman in Turkey, the trail of destruction of hurricane Katrina, which passed through the American state of Louisiana in 2005, until arriving in the Hall of Mirrors in the Palace of Versailles. After the creation of the universe and the close of the dancer's eyes, time begins to transform into human time gradually.

Mirrors have a fundamental symbolic role. They represent man's awareness of himself and his relationship to the cosmos. This relationship constitutes in a conflict, as in the case of the destruction caused by hurricane Katrina. This conflict can be resolved with an agreement with a creator of the universe. That is why many scenes portray religiosity, as in the scenes of baptisms. 
Baptism represents this union between the human and the divine in an attempt to keep the cosmos working for humanity. It is also shown the sculptures representing the baptism of Clovis, the first king of the Franks who ruled between the fifth and sixth centuries of our era. Here, besides the religious element there is the political situation, since when the king is converted the whole kingdom and its subjects are converted. Later monarchs began to be seen as representatives of God on Earth, responsible for maintaining order in the cosmos.

After the baptism, it begins another long sequence of images of waterfalls, canyons and glaciers, which represents the planet in its pure state. Until arriving at the African natives of the Valley of Omo, in Ethiopia. The natives are the last representatives of the first form of production of human existence, which comprises the communities of hunter-gatherers. These communities represent the harmonious communion between humans and nature, in which the impacts of man on the environment are minimal. With agriculture and complex industrial and urban society of today, which are shown in the film, the form of existence of production becomes more complex and develop into increasingly abstract and imaginatively produced, which is represented by the vast office shed. If before only hunters and collectors for subsistence, now the vast majority of human beings spend most of the day confined in offices or assembly lines in the industry (represented by the scenes of factories). The production form of human existence transcends 
hunting and gathering for survival and shall be based on abstract and complex symbolic systems, such as money, consumerism and the creation of needs that did not exist before. The man and the robot represent the reification of man and the humanization of things. This fact impacts human consciousness.

It is in the performance of Olivier de Sagazan that we can see the texture of the plot being constructed. No longer a hunter-gatherer, but an employee of any company at his desk with pens, staplers, papers, and telephone. His performance occurs between two images of a female robot, which symbolizes the transformation of man into machine through his mechanized work. This work suffocates the human in which is symbolized in the performance of Sagazan with his face being covered with clay. In this scene, we can see a reaction of man to the cycle of samsara. The suit and tie being torn in a man's reaction to the mechanization of labor. Getting away from himself.

Here arises one of the features of the film that is the digression. In the following scenes are shown the ways of life that led the humanity to the feeling of imprisonment in itself. One of the ways to escape from itself is in the variety forms of entertainment. In the following scenes are shown images of entertainment, being the most singular moment the ski resort of Dubai.

The production cycle is represented by the Chinese irons factory, the car industry and the consequent industry of recycling products and demolishing cars. What is done is consequently 
destroyed. The mass production of technological products generates the problem of the production of wastes that bring an environmental impact to the planet.

The entire feeding cycle is shown in the following scenes. The food industry with the production of poultry and pigs in a farm in Denmark and the chicken processing factory in China. Then we are brought to the supermarkets and a fast-food restaurant where obese people feed themselves. The consequence of this is demonstrated by the man with morbid obesity getting ready for surgery. Here the unbridled mode of consumption leads to the mass and industrial production of chickens, pigs and dairy products, which are treated as consumer goods.

Not only animals became objects of consumption, but people themselves. In the following scenes we can see a woman getting ready for plastic surgery and prostitutes in Thailand who dance with numbers nailed to her bikinis. Then, we see a Japanese geisha, who cries. Her crying symbolizes the growing dehumanization, which seems to perpetuate the cycle of samsara. An irreversible domino effect.

The contradictory journey of human existence is also demonstrated in the forms of housing. Some scenes show images of slums all over the world, which seems to portray also a kind of social imprisonment. The maximum of human contradiction is shown in the contrast between the favela of Paraisópolis and a high-standard building in Morumbi, neighbourhood of São Paulo, with its 
swimming pools on each porch. In addition to social imprisonment, there is also the imprisonment in jails represented by the Cebu prison in the Philippines. The inmates dance while they are watched by the inmates in their cells. The contradiction here is symbolized by dance, which portrays the freedom of the body, but from within a penitentiary. That is, the contradiction between freedom and incarceration.

In the next sequence coffins are shown in unusual shapes. In one of them, a man is going to be buried inside a coffin in the form of a pistol. In a process of narrative reconstruction through the temporal sequence, demonstrating the effect of cause and effect, which generates more causes and more effects, each scene historically reconstructs the following. After the man's burial in a pistol coffin is shown the process of making weapons in an industry in the Philippines. Then, later appear the same African natives from the beginning of the film, but now they are armed. The alleged pure state of the hunter-gatherer man living in harmonious coexistence with the environment is now disturbed by the fact that they are armed. That is not restricted to this community, but even a family is armed, as we see in the scene of the father and the two armed brothers. Human belligerence creates the effect of the physical deformity of an American soldier, who is standing in a graveyard for war veterans in Los Angeles. It also generates divisions among people, such as the scene in the demilitarized zone of Korea and the wall of the West Bank that divides the Palestinian territories from Israel. The choice to show the phrase "I want my ball back!" 
in the wall does not seem to be banal, since we could allude to "I want my freedom back!". At the border, a car is sniffed by a dog looking for signs of explosives.

Then various religious images are shown, such as Jews praying at the Wailing Wall, Muslims circling the Kaaba in Mecca and images of St. Peter's Basilica in the Vatican. Here there are indications of the end of the film, since, after all the plot being constructed through the contradictory relation of the man with himself and with the cosmos, seeing itself in situations of sufferings whose causes were created by himself, the religion proposes a salvation of pain caused by this contradictory relation to time. The three monotheistic Abrahamic religions ${ }^{2}$ propose, after death, the salvation of the soul by going to an eternal paradise where there are no more conflicts. That is, a place outside samsara, out of time and narrative.

Finally, we return to the Ladakh monastery at the beginning of the film. There, the monks contemplate the mandala. Then, carefully, they erase it. They reduce everything to powder and put it in a pot. We come back now to the girl in the One Thousand Hands Dance, from the beginning of the film. Now she opens her eyes and they dance. It seems that everything that happened in the film occurred between the blink of an eye of the dancer. 
Then more scenes are shown in the desert in Namibia, alluding to the resumption of everything, since the desert represents emptiness, but an emptiness that can be constitutive in the recreation of new beginnings, characteristic of samsara.

\section{Conclusion}

In a possible reading of the film Samsara I was able to show the search of the film in demonstrating the causes and consequences of human actions in their relationship with the universe, the environment and the narrative temporality. We have seen the demonstration of the butterfly effect, in which small actions have great consequences. Samsara is represented by the cycle of situations that cause more situations that generate endless consequences. By demonstrating this cycle the directors were able to provide the audience with awareness of diverse issues, such as the transformation of the environment by humanity, food production, the entertainment industry, wars, religions, and the human psyche. Public awareness is relevant when we imagine that many of the relationships portrayed in the film occur unconsciously in the social imaginary, which generates the environmental problems that humanity faces in modernity and a poor prognosis when we think about global warming and its consequences.

The framework of discourse analysis was adequate for the proposition of possible readings of the film. The directors left the film without any speech, which places the audience in the task 
of constructing the story according to the discursive formations of each one. The audience is urged

to look for interdiscourses, that is, discourses and senses already historically constructed to establish a connection between the images. In each of the discursive formations there could be a possible reading. Hence, the ideas of Paul Ricoeur on the relations between time and narrative proved fruitful to establish a story for the set of images without a traditional narrator. The narrator in Samsara can only be known when we establish a link between the images and the consequences of the proposed actions. With the linking of history we were also able to identify the various contradictory points of human existence and their relationship, also contradictory, with the environment. These contradictions are part of the plot and intrigue of the narrative of human experience in its cosmos.

By following the story I was able to establish narrative insights that helped to understand it and to propose the motivations of Ron Fricke and Mark Magidson for the film.

\section{REFERENCES}

Montgomery, Martin and Allan, Stuart. Ideology, Discourse, and Cultural Studies: The Contribution of Michel Pêcheux. Canadian Journal of Communication, Vancouver, v. 17, n. 2, 1992. 
Orlandi, Eni Puccinelli. Análise de discurso: princípios e procedimentos. Campinas: Pontes, 2005.

. Papel da memória. In: ACHARD, Pierre et al. Papel da memória. Campinas: Pontes,

1999.

Pêcheux, Michel. Semântica e discurso: uma crítica a afirmação do óbvio. Campinas: Editora da Unicamp,

1988.

Ricoeur, Paul. Tempo e narrativa: Tomo I. São Paulo: Papirus, 1997.

. Narratividad, fenomenología y hermenéutica. Revista Anàlisi: quaderns de comunicació

i cultura, Barcelona, n. 25, 2000.

${ }^{1}$ Available at: <https://www.barakasamsara.com/samsara/about>. [Accessed April 20, 2019].

${ }^{2}$ Judaism, Christianity and Islam. 